\title{
Antiangiogenic Tumor Therapy
}

\author{
Darren W. Davis, David J. McConkey, Wei Zhang, and Roy S. Herbst \\ The University of Texas M.D. Anderson Cancer Center, Houston, TX, USA
}

BioTechniques 34:1048-1063 (May 2003)

\section{INTRODUCTION}

The term angiogenesis was first used in 1787 by a British surgeon, Dr. John Hunter, to describe vessels growing in the antlers of reindeer. Since then, angiogenesis has been shown to be involved in embryonic development, tissue regeneration, and chronic inflammatory conditions (1). However, it was arguably Folkman's recognition of the importance of angiogenesis for tumor growth in 1971 (2), combined with the first successful treatment of an angiogenesis-dependent pulmonary hemangioma (a benign tumor) with interferon $\alpha-2 \mathrm{a}$, that enabled physicians and scientists to recognize the potential therapeutic benefit of using angiogenesis inhibitors as therapy against cancer (3). Soon after, the first clinical trial of an antiangiogenic agent, TNP-470, began in cancer patients (4). In 1999, the development of antiangiogenic therapies for cancer became a top priority of the U.S. National Cancer Institute (Bethesda, MD, USA).

The research and development of angiogenesis-based medicines represent one of the most heavily funded areas of medical research in history. There are currently more than 200 anticancer agents in various stages of clinical development, including 39 antiangiogenic agents in clinical trials for the treatment of solid tumors. Although the Food and Drug Administration has approved other therapeutic modalities that affect angiogenesis (e.g., Regranex ${ }^{\circledR}$, an angiogenesis-stimulating drug for the treatment of diabetic foot ulcers; Ortho-McNeil Pharmaceutical, Raritan, NJ, USA), none have been approved for the treatment of cancer. This report describes the unique aspects of targeting angiogenesis and the challenges associated with the clinical development of this new class of drugs.

\section{A BIOLOGICAL TARGET FOR TUMOR THERAPY}

Tumor angiogenesis is dependent on the proliferation and migration of endothelial cells to provide nutrients and oxygen to the tumor (4a). Therefore, tumor vascular endothelial cells have become an important target in the development of antiangiogenic drugs. Targeting cells that support tumor growth offers several unique advantages over conventional cytotoxic chemotherapies. For example, the recruitment of endothelial cells occurs early during angiogenesis (5); therefore, targeting endothelial cells provides an early opportunity to inhibit neo-vessel formation. Endothelial cells are genetically stable and thus are less likely to accumulate mutations that enable them to acquire a drug-resistant phenotype $(6,7)$. In addition, endothelial cells are easily accessible via the circulation, which allows for the optimal delivery and homogeneous distribution of drugs within the tumor. Furthermore, the collapse of a single capillary within the tumor may amplify an antiangiogenic effect. These potentially therapeutic advantages have led to the strategic development of three major types of angiogenesis inhibitors: direct, indirect, and multiple targets (Figure 1).

Many of the antiangiogenic agents that affect tumors through their vasculature act in a cytostatic or growth-delaying fashion $(8,9)$. These putative inhibitors of angiogenesis act directly on endothelial cells to prevent proliferation or migration in response to pro-angiogenic proteins, such as vascular endothelial growth factor receptor (VEGF), basic fibroblast growth factor receptor (bFGF), and platelet-derived endothelial growth factor- $\beta$ (PDGF- $\beta$ ) $(10,11)$. These proteins are responsible for stimulating blood vessel growth early in tumorigenesis (12) and are secreted by tumor cells, endothelial cells, or both. Several potential strategies for interrupting the signaling pathways of pro-angiogenic proteins include neutralizing the protein in the microcirculation or preventing the binding of the ligand to its cognate receptor and blocking signal transduction by targeting the intracellular domains of receptor tyrosine kinases (RTKs). The inhibition of signal transduction pathways is likely to induce apoptosis in endothelial cells, subsequently killing surrounding tumor cells (13-15). Other antiangiogenic drugs act indirectly on endothelial cells by targeting tumor cells to prevent the expression of or inhibit the activity of tumor proteins that stimulate angiogenesis. For example, inhibiting the activity of the epidermal growth factor receptor (EGFR) blocks the synthesis of VEGF, $\mathrm{bFGF}$, and transforming growth factor- $\alpha(16,17)$. Perhaps the most encouraging approach to inhibit tumor angiogenesis is to combine the direct and indirect targeting approaches (18). Agents that simultaneously block the secretion of multiple pro-angiogenic factors and receptor activity are likely to have the most optimal therapeutic benefit. All three types of potential antiangiogenic therapies are in clinical trials, and many more molecular variants, such as drugs that inhibit all three cognate receptors of the VEGF receptor (VEGFR), are being developed. 


\section{Commentary}

\section{CLINICAL DEVELOPMENT OF ANTIANGIOGENIC DRUGS}

Almost 20 years ago, the first cloning and sequence analysis of a cDNA encoding a cell surface protein, the human EGFR, was chosen as a prototype drug discovery target for cancer (19). A decade later, the first genomic research-based RTK inhibitor, Herceptin ${ }^{\circledR}$ (Genentech, South San Francisco, CA, USA), was approved for breast cancer therapy against ErbB-2/HER2/neu (a proto-oncogene that encodes the production of a ligandless receptor protein) positive tumors $(20,21)$. Genome-based assays are routinely used for patient selection of ErbB2-positive breast cancers (22). The antitumor activity of Herceptin provided proof of principle for therapies that target RTKs, a class of cell surface receptors with intrinsic tyrosine kinase activity (23). Since then, cancer genomics has contributed tremendous progress toward the discovery and development of many small-molecule angiogenesis inhibitors. The most clinically advanced genome-based cancer drug is gefitinib (Iressa ${ }^{\circledR}$, AstraZeneca, London, UK), which targets the ErbB family of RTKs. Now in Phase III trials, Iressa has demonstrated activity in non-small-cell lung, head and neck, and hormone-resistant prostate cancer (24-27). However, in contrast to the relationship between ErbB-2 expression and Herceptin activity, the efficacy of Iressa is not directly related to the level of EGFR expression (28). Thus, optimizing the efficacy of Iressa in different cancers has been challenging, and the identification of better predictive markers for Iressa activity is imperative to maximize therapeutic bene- fit. Microarray expression analysis should prove beneficial for identifying potential prognostic markers.

Almost a third of the molecular therapeutics in clinical development target VEGF or its RTK (VEGFR-2). The VEGF RTKs are single-pass transmembrane proteins that affect cell proliferation, differentiation, migration, and metabolism (29,30). Of the three VEGF receptors, VEGFR-2 is exclusively expressed on endothelial cells and plays an essential role in tumor neovascularization $(31,32)$. Thus, drug-targeted therapy against VEGFR-2 has become a central focus in antiangiogenic drug development. In preclinical studies, inhibiting the function of VEGFR-2 in endothelial cells demonstrated efficacy against solid tumors and provided optimistic results for clinical investigation (33). However, clinical trials with these agents used as a monotherapy have, overall, demonstrated little efficacy against solid tumors. Among the VEGFR-2 inhibitors, Sugen's SU5416 ${ }^{\circledR}$ (South San Francisco, CA, USA) has progressed the furthest in clinical development and is now being studied in combination with conventional cytotoxic agents $(34,35)$.

Other strategies include targeting enzymes that are essential for angiogenesis. The matrix metalloproteinases (MMPs) are a family of proteinases capable of digesting the extracellular matrix, which is a key process necessary for tumor growth and metastasis $(36,37)$. In humans, the overexpression of MMPs has been shown to correlate with metastatic potential and poor prognosis $(37,38)$. Therefore, blocking the activity of MMPs has become an important target to inhibit angiogenesis. Similar to other novel antiangiogenic agents, clinical trials with these agents have failed to reduce tumor burden in patients with advanced disease $(39,40)$. However, a large number of patients have demonstrated stable disease, following treatment with MMP inhibitors $(41,42)$.

The precise molecular mechanism(s) of many agents with potentially effective antiangiogenic properties remain unknown (e.g., thalidomide). Clinical studies of these unique agents have demonstrated that some patients experience tumor regression or disease stabilization with prolonged therapy (8). Further studies are needed to evaluate these promising angiogenesis inhibitors in newly diagnosed patients and/or at the time of minimal residual disease. Studies suggest that combining antiangiogenic agents with traditional cytotoxic therapies will provide the most therapeutic benefit $(43,44)$. Indeed, a number of antiangiogenic agents are in clinical development either as a monotherapy or multimodality strategy for the treatment of solid tumors (Table 1).
Figure 1. Three major types of antiangiogenic agents in clinical development to treat solid tumors. Direct angiogenesis inhibitors target endothelial cells to prevent them from proliferating, migrating, or avoiding apoptosis in response to pro-angiogenic proteins. Indirect angiogenesis inhibitors target tumor cells and block the secretion or activity of pro-angiogenic proteins that stimulate tumor-associated endothelial cells. Agents that inhibit multiple signal transduction pathways on both tumor-associated endothelial cells and tumor cells may provide the best therapeutic approach for inhibiting angiogenesis in advanced disease. 


\section{Commentary}

\section{UNIQUE CHALLENGES OF ANTIANGIOGENIC THERAPY}

Preclinical studies indicate that the cytostatic nature of angiogenesis inhibitors makes them more effective when they are administered at a low, continuous dose to maintain a constant concentration in the circulation. In addition, clinical studies have shown that angiogenesis inhibitors are well tolerated and optimal at concentrations well below the maximum dose studied $(39,45)$. Cytotoxic drugs, in contrast, are usually administered at the maximum tolerated doses, which are determined by the dose-limiting toxicity (46). Traditionally, this paradigm is used to provide an estimate of the active dose range for subsequent clinical trials. However, because there is an uncertain relationship between toxicity and response with angiogenesis inhibitors, the clinical end points used to determine the efficacy of cytotoxic drugs do not apply to antiangiogenic therapy. Thus, determining the optimal biological dose of antiangiogenic agents depends on a different logic than is required for cytotoxic therapy (47). Establishing the optimal dose and schedule to reduce the blood supply to the tumor has been a major clinical challenge (48).

\section{SURROGATE MARKERS OF ANTIANGIOGENIC ACTIVITY}

The complexity of monitoring biological responses of angiogenesis inhibitors has accentuated the need to develop surrogate markers to assess antiangiogenic activity. A feasible and routinely used approach is to measure angiogenic protein levels that can be detected in serum, plasma, or urine. The successful interruption of angiogenic pathways might be expected to lead to changes in protein levels that are hypothesized to be direct or indirect targets of the inhibitor. Although several angiogenic factors have been assessed in clinical studies with various angiogenesis inhibitors, most have failed to demonstrate a correlation with clinical response. Interestingly, urine VEGF levels measured before treatment have proven useful as a prognostic indicator for patients with disease stabilization versus progressive disease $(35,49)$. The limitations associated with monitoring angiogenic protein levels include the sensitivity of the assay used to measure the protein. In addition, angiogenic protein levels may be slightly inhibited within the tumor microenvironment so that detecting significant changes in the circulation or urine may be impractical. Furthermore, different tumors may produce varying levels of angiogenic proteins. Additional studies are needed in homogeneous patient populations to determine the value of monitoring angiogenic proteins as surrogate markers of antiangiogenic activity.

A recent strategy for monitoring antiangiogenic activity is by ex vivo analysis of isolated peripheral blood cells. Although these methods are still exploratory, using four-color flow cytometry to quantify circulating endothelial cells is encouraging (50). Recent data suggest that angiogenesis is supported by the VEGF-dependent mobilization of bone marrow-derived circulating endothelial precursors (CEPs) (51). Clinical studies have revealed that angiogenesis inhibitors decrease enough CEPs to the level where a small change $(<1 \%)$ in the cell populations is detectable by flow cytometry. Investigators have hypothesized that antiangiogenic targeted therapy increases the number of mature circulating endothelial cells (CECs) by causing damage to the endothelium (52). In a Phase I study with ZD6126, a tubulin-binding agent, increases in mature CECs were observed as early as $6 \mathrm{~h}$ after treatment in four out of five patients (53). Although this approach is encouraging, validation is necessary to establish a correlation with clinical outcome.

Several noninvasive radiologic techniques that show promise for measuring the effects of antiangiogenic activity include positron emission tomography, magnetic resonance imaging, dynamic computed tomography, and 3 -D ultrasound $(35,42)$. It is expected that successful inhibition of angiogenesis might lead to decreased blood flow and/or volume, resulting in decreased vascular permeability (48). Each of these surrogate end points is being measured by all of the aforementioned radiologic methods. Although it is still too early to tell which of these imaging methods will be superior, it is likely that a combination may be required to monitor biological activity and tumor response.

The use of gene expression microarrays can be invaluable in the discovery of diagnostic and prognostic biomarkers of biological response to angiogenesis inhibitors. The identification of subsets of patients who are most likely to benefit from investigational agents is greatly needed, especially during early clinical studies. In addition, microarray technology would be most beneficial to confirm the molecular mechanisms of investigational agents. Although a molecular target may be therapeutically attractive, not all will prove pharmacologically or biologically practicable. Inhibiting the active sites of some enzymes may be limited by structural conformation. Thus, it is important to identify pharmacodynamic biomarkers to confirm that drug-target inhibition has been achieved. Clearly, the use of genomic markers will become increasingly important to enable the selection of patients whose tumors are most likely to respond to molecular therapeutics. Indeed, preclinical and clinical studies with Iressa and Herceptin (and STI571) have provided proof of concept that biological activity and therapeutic benefit occur via hypothesized mechanisms.

\section{LASER-SCANNING CYTOMETRY (LSC) ANALYSIS OF RTK ACTIVITY}

Genomics and proteomics should complement each other for a comprehensive understanding of the cell system and biological influence of molecular targeted therapy. The proteome provides a platform for conducting integrated protein analysis. Thus, proteomics is the study of protein properties including post-translational modification, expression, enzymatic regulation, and protein-pro- 


\section{Commentary}

Table 1. Antiangiogenic Agents in Clinical Trials

\begin{tabular}{|c|c|c|}
\hline Agent (Published Results) & Antiangiogenic Target & Phase \\
\hline \multicolumn{3}{|l|}{ Direct Inhibitors } \\
\hline VEGF Trap & Decoy-soluble receptor for VEGF & 1 \\
\hline 2-Methoxyestradiol & Induces apoptosis in endothelial cells & 1 \\
\hline Carboxyamidotriazole (65) & Inhibitor of calcium influx (endothelium) & I \\
\hline Combretastatin A4 Phosphate & Anti-Tubulin binding agent & 1 \\
\hline EMD 121974, Vitaxin (67), S-247 & $\alpha(v) \beta(3)$ integrin antagonists & 1 \\
\hline Razoxane (49) & Topoisomerase II inhibitor & II \\
\hline $\begin{array}{l}\text { Phase I: PTK } 787 \text { (81), ZK22584 (RTK inhibitors), } \\
\text { HuMV833 (MAb) (82) }\end{array}$ & VEGF receptor antagonist & $\mathrm{I} / \mathrm{II} / \mathrm{II}$ \\
\hline \multicolumn{3}{|l|}{$\begin{array}{l}\text { Phase II: RhuMab (MAb) (83), Angiozyme } \\
\text { (ribozyme) (84) }\end{array}$} \\
\hline \multicolumn{3}{|l|}{ Phase III: Bevacizumab (MAb) $(85,86)$} \\
\hline Phase I:IMC-1C11, ZD6474, AG13736 & VEGFR-2 antagonist & $\mathrm{I} / \mathrm{II} / \mathrm{II}$ \\
\hline $\begin{array}{l}\text { Phase II/III: SU5416 (Semaxanib, single) } \\
\text { (35) w/ Paclitaxel, w/ Gemcitabine \& } \\
\text { Cisplatin (34), \& w/ Irinotecan \& Cisplatin }\end{array}$ & & \\
\hline TNP-470 (43) & Inhibits endothelial cell proliferation & 1 \\
\hline \multicolumn{3}{|l|}{ Indirect Inhibitors } \\
\hline Halofuginone Hydrobromide & Type I collagen inhibitor & 1 \\
\hline Interleukin-12 and Interleukin-2 (68) & Induces CD8+ T-cell receptor $\& \alpha \beta+$ T cells & 1 \\
\hline LY317615 and Capecitabine & Protein kinase $C \beta$ inhibitor & 1 \\
\hline Carboxyamidotriazole (CAI, single) \& w/ paclitaxel (65) & Inhibitor of calcium influx (endothelium) & I \\
\hline $\begin{array}{l}\text { Phase l: ABX EGF, Cl-1033, PKI-166, EGF-Vaccine, } \\
\text { EKB-569, GW2016, ICR-62, EMD } 55900(88,89) \\
\text { CP358 (774), PD153035, AG1478 }\end{array}$ & EGFR & $\mathrm{I} / \mathrm{II} / \mathrm{II}$ \\
\hline \multicolumn{3}{|l|}{$\begin{array}{l}\text { Phase II/III:IMC-C225 (Erbitux) (90), ZD1839 (Iressa) } \\
\text { (24-27,91), OSI-774 (92) }\end{array}$} \\
\hline \multicolumn{3}{|l|}{ Phase III:Erlotinib (Tarceva) (93) } \\
\hline Squalamine Lactate (MSI-1256F) (76) & Inhibits brush-border isoform NHE3 & 1 \\
\hline PNU-145156E (99) & Inhibits pro-angiogenic factors & 1 \\
\hline Tetrathiomolybdate (45) & Anti-copper agent & 1 \\
\hline 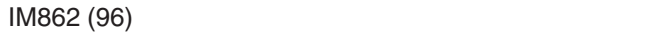 & Activate NK cells & 1 \\
\hline \multicolumn{3}{|l|}{ Multiple Targets } \\
\hline BAY 12-9566 (single) \& Fluorouracil or Doxorubicin (75) & Metalloproteinase Inhibitor-2, $-3,-9$ & 1 \\
\hline SU101 $(94,95)$, SU6668, SU11248 & PDGFR, VEGFR, bFGF & 1 \\
\hline $\begin{array}{l}\text { Neovastat (Anti-VEGF) }(97,98) \text {, Marimastat (40), } \\
\text { Prinomastat, BMS-275291, COL-3 (42), MM1270 (41) }\end{array}$ & MMP inhibitors & $\mathrm{I} / \mathrm{II} / \mathrm{III}$ \\
\hline \multicolumn{3}{|l|}{ Unknown? } \\
\hline $\begin{array}{l}\text { Thalidomide (single) (69-72), or w/ } \\
\text { Docetaxel (73), or w/ Cyclophosphamide }\end{array}$ & Unclear, TNF Antagonist & 1 \\
\hline Radiation w/ Thalidomide \& Temozolomide (74) & Unclear, TNF Antagonist & 1 \\
\hline Tecogalan & Unknown & 1 \\
\hline Temozolomide \& PEG-Interferon $\alpha-2 b$ (89) & Unknown & I \\
\hline Dimethylxanthenone Acetic Acid (77) & Unclear, induces TNF- $\alpha$ and Nitric Oxide I & \\
\hline Endostatin $(48,60,78-80)$, Angiostatin & Unknown & 1 \\
\hline CC-5013 (66) & Immunomodulatory derivative of thalidomide & 1 \\
\hline
\end{tabular}

tein interactions (54). Over the past few years, the field of proteomics has made remarkable advances in understanding the complex interactions between proteins and the biological response to extracellular signals.

Understanding functional proteomics (e.g., phosphorylation of RTKs) has become critically important for the clinical development of molecular targeted therapy. Antiangiogenic drugs that target RTKs are designed to block the intrinsic enzymatic activity that catalyzes the transfer of the $\gamma$-phosphate of ATP to tyrosine residues in protein substrates (30). Inhibiting the phosphorylation of these tyrosine residues prevents downstream signaling events, which affect cellular function (e.g., proliferation, differentiation, migration, or apoptosis) (29). We have developed a quantitative method for monitoring drug-target interactions at the molecular level. Although LSC technology is not high throughput, it has been useful for confirming the molecular mechanisms of (high-content analysis) investigational angiogenesis inhibitors.

The VEGFR-2 has received the most attention as a possible target for antiangiogenic therapy. However, more traditional growth factor receptors also appear to play essential roles in angiogenesis, as introduced earlier for EGF/EGFR and ErbB2. Another growth factor that plays a 


\section{Commentary}

role in angiogenesis is the platelet-derived growth factor (PDGF) (55). PDGF and its cognate receptor (PDGFR) are expressed by a wide variety of solid tumors including glioblastoma, melanoma, gastric, lung, and prostate cancer, in which they are believed to contribute to autocrine growth stimulatory loops that are important for tumor progression $(56,57)$. Recent data suggest that endothelial cells appear to express phosphorylated PDGFR when they are exposed to tumor cells that express PDGF (58). Furthermore, preclinical studies with SU6668, a nonspecific TK inhibitor of VEGFR-2, PDGF- $\beta$, and bFGF (with less affinity), have revealed that these RTKs have the potential to induce apoptosis in tumor-associated endothelial cells and tumor cells, significantly reducing tumor burden (59). However, clinical studies with these compounds have been disappointing because of the lack of antitumor activity observed in patients (35). Therefore, it has become critically important to determine whether these small molecules inhibit phosphorylation of the hypothesized RTK target(s) in patient tumors, especially to determine the validity of the RTKs (VEGFR) as potentially effective antiangiogenic targets. Thus, LSCbased technology is capable of measuring biochemical responses such as changes in the level of phosphorylation of target proteins.

LSC-mediated quantitative analysis is similar to fluorescence-activated cell sorting because it is capable of identifying individual cells within a tumor cross-section based on immunofluorescence staining. The laser-based platform is capable of simultaneously detecting up to five
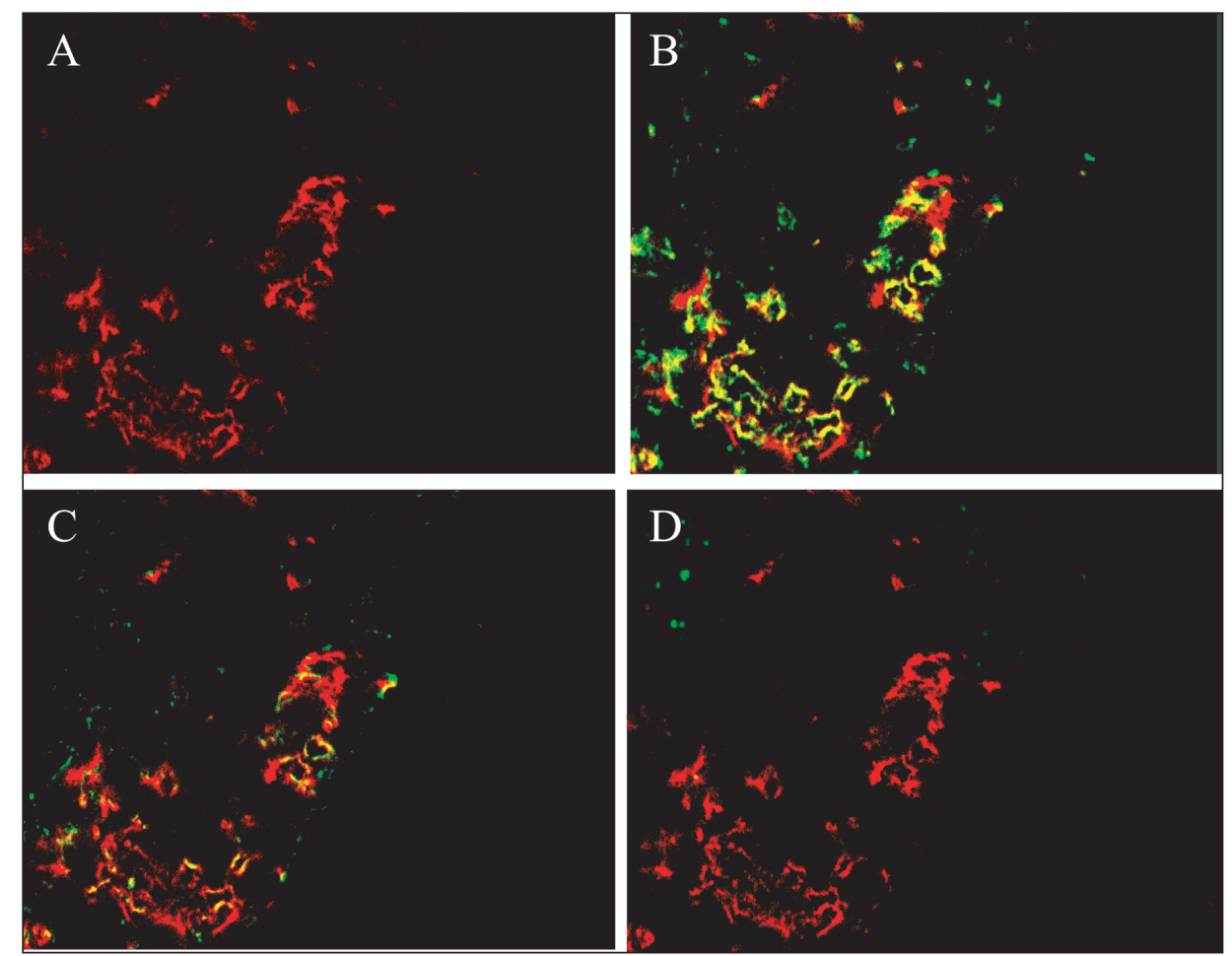

Figure 2. Effects of SU6668 on multiple RTK targets. Representative patient biopsy obtained after 28 days of SU6668 treatment was processed and immunofluorescently stained (simultaneously) for endothelial cells [CD31, (red)], phosphorylated PDGF- $\beta$ (green), phosphorylated VEGFR-2 (green), and DNA fragmentation (terminal-deoxynucleotidyl-transferase dUTP nick-end labeling, TUNEL) (green). Images shown are LSC-generated scanned images superimposed and pseudo-colored for visualization of (A) $\mathrm{CD} 31^{+}$cells, (B) $\mathrm{CD} 31^{+} /$phosphorylated-PDGF- $\beta^{+},(\mathrm{C}) \mathrm{CD} 31^{+} /$phosphorylated-VEGFR-2 ${ }^{+}$, and (D) CD $31^{+} / \mathrm{TUNEL}^{+}$

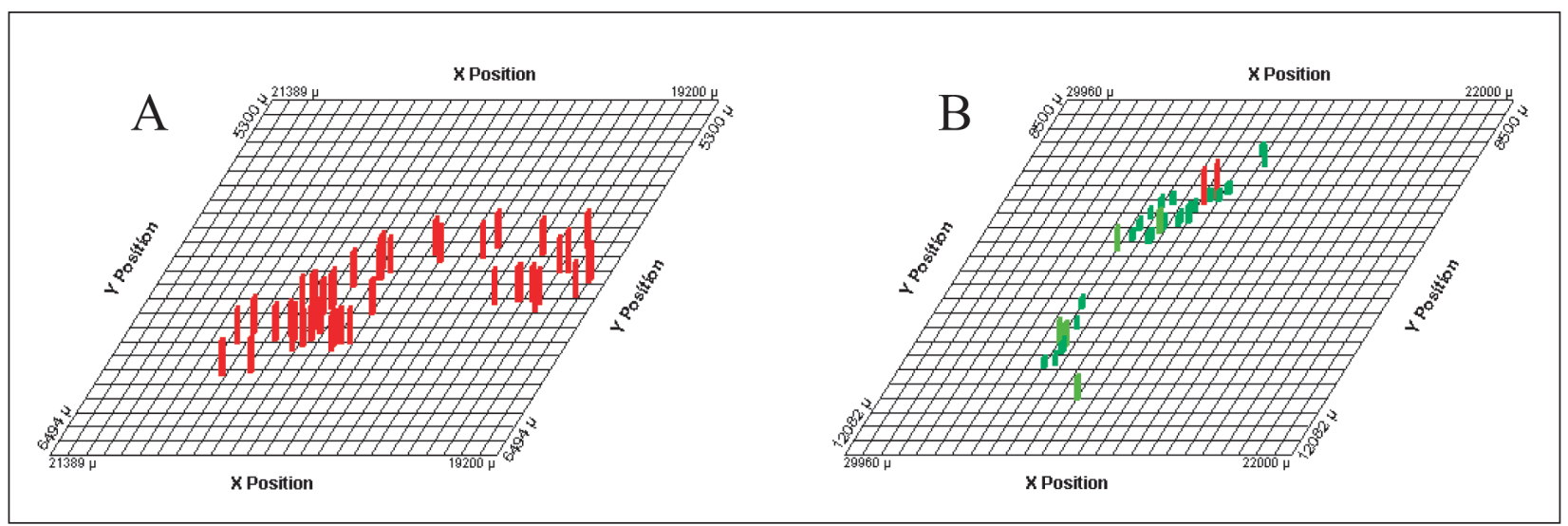

Figure 3. LSC-mediated quantitative analysis of the effects of SU6668 on phophorylated-VEGFR-2. Patient biopsies obtained before and 28 days after SU6668 treatment were immunofluorescently stained (see Figure 2) and scanned by LSC to determine the levels of phosphorylated-VEGFR-2 in endothelial cells. The 3-D tissues maps display the location of endothelial cells (bars) within each tissue section and the intensity of phosphorylated-VEGFR-2 (red, high phosphorylation; green/blue, low phosphorylation) (A) before and (B) after SU6668 treatment. In this particular patient, SU6668 treatment slightly decreased phosphorylation of VEGFR-2. 


\section{Commentary}

fluorochromes; therefore, it is extremely powerful for analyzing multiple drug targets (RTKs) and effects on cellular function (e.g., cell death). In our Phase I trial of SU6668, we investigated the inhibitory effects of this small molecule on its putative targets by synchronized immunofluorescent analysis of phosphorylated PDGF- $\beta$ and VEGFR-2 and whether the inhibitory effects were sufficient to induce apoptosis in endothelial cells (Figure 2). Patient biopsies obtained before and 28 days after daily SU6668 treatment were subsequently analyzed using LSC technology to determine the levels of phosphorylation of the RTKs (Figure 3). Preliminary results indicate that the effects of SU6668 on blocking phosphorylation of PDGF$\beta$ and VEGFR-2 were heterogeneous and that the levels of cell death were very low among the patients studied (D.W.
Davis, et. al., manuscript in preparation). In collaboration with other investigators, we have also initiated the analysis of the molecular effects of SU5416 in patient biopsy specimens to determine the validity of targeting VEGFR2 and to inhibit its activity in solid tumors.

The analysis of surrogate markers in patient biopsies obtained before and at specified time points after therapy has provided new insights for monitoring putative antiangiogenic activity $(48,60)$. Importantly, the ability to measure drug-target effects at the molecular level can provide early proof of whether an antiangiogenic agent has successfully reached its intended target. An important end point of antiangiogenic tumor therapy is assessing apoptosis in endothelial cells $(13,15,61)$. Thus, discerning clear patterns of cell death may be important to optimize the dose and schedule of antiangiogenic agents in Phase I and II studies, especially in the absence of little or no toxicity. LSC-mediated analysis of apoptosis in patient biopsy specimens obtained $48 \mathrm{~h}$ after the initiation of the treatment has proven useful for predicting patient response to neoadjuvant therapy for breast cancer (62).

\section{LIMITATIONS AND FUTURE DIRECTIONS}

Although antiangiogenic agents have shown great promise in preclinical cancer models, investigators are beginning to realize that developing clinically useful antiangiogenic therapy will be more challenging than originally thought. This likely reflects our limited understanding of tumor vessel biology and how tumor cells crosstalk with tumorassociated endothelial cells. The following issues will have to be considered and investigated. First, we will need to know the redundancy of angiogenic factors. It is obvious that targeting one of potentially many factors will have a limited effect. The lessons we learned from knockout mouse studies apply here. Second, we will need to know what is unique about tumor vessels compared with normal vessels. Many of the factors we target in therapy are also important for normal angiogenesis, limiting the dose that can be applied. There is clear evidence from pathology studies that tumor vessels are different from normal vessels; for example, there are many large vessels in tumors as compared to normal angiogenic processes. Indeed, a transcriptome analysis of vessels from normal and tumor tissues revealed unique gene expression patterns in tumor vessels (63). Another example is offered from studies of human brain tumors. In normal brain, the blood vessels provide a barrier, called the blood-brain barrier, which limits the transport of biological agents from the 


\section{Commentary}

blood to the brain. However, in brain tumors, this barrier is broken down, and the vessels become much more permeable. Furthermore, our gene expression profiling, coupled with immunohistochemistry analysis, demonstrated that $\mathrm{CD}^{+}$diffuse large B-cell lymphomas (DLBCL) express CD36 on the large blood vessels, whereas CD5- DLBCLs do not express CD36 on their vessel cells (64). Finally, we will need to know how tumor cells functionally modify endothelial cells, much like we need to know how tumor cells manage to counteract the immune cells often found in tumor tissues. The heterogeneity found in different types of tumors may affect the tumor vasculature in dissimilar ways.

A better understanding of how angiogenesis inhibitors affect their target and the consequential effects on surrounding tumor and stromal cells is necessary for successful translation into the clinic. In addition, it has become clear that, given the multitude of proangiogenic pathways, the successful blockade of angiogenesis will require inhibitors with multiple targets or combinations of agents. Thus, therapeutic agents that target multiple receptors or steps to malignant progression are more likely to demonstrate a clinical benefit against advanced disease. It may therefore be prudent to design drugs that simultaneously target multiple growth factors or receptors. Novel agents that target both the VEGFR and EGFR will begin clinical trials this year. In addition, combining agents that have direct and indirect effects on angiogenesis with conventional cytotoxic modalities may be extremely beneficial for patients with advanced cancer. Nonetheless, it will be critically important to monitor surrogate markers of antiangiogenic activity in patients receiving multimodality therapy and to tailor patient-specific therapy on the basis of the tumor's response over time. The development and validation of new methods to monitor surrogate markers of antiangiogenic activity are essential for optimizing the biological therapeutic benefit, for only then will it be possible to choose the correct dose for this combination. Undeniably, lessons learned from the successful development of Herceptin and Gleevac have shifted the strategy in drug development and cancer therapy. Genomic and proteomic-based technologies will be needed to develop better molecular targets, diagnostic and prognostic markers that can be used to assess the optimal activity of angiogenesis inhibitors (Figure 4).

The development of high-throughput genomic and proteomic technologies has begun to help us acquire some of the information pertaining to the above questions. We expect that the application of genomics in vessel research in the next few years will illustrate a more comprehensive picture of tumor vessel biology. A highly anticipated outcome of this research effort is the identification of specific targets that will result in more effective antiangiogenic therapy.

\section{REFERENCES}

1.Carmeliet, P. 2000. Mechanisms of angiogenesis and arteriogenesis. Nat. Med. 6:389-395.

2.Folkman, J. 1971. Tumor angiogenesis: therapeutic implications. N. Engl. J.
Med. 285:1182-1186.

3.White, C.W., H.M. Sondheimer, E.C. Crouch, H. Wilson, and L.L. Fan. 1989. Treatment of pulmonary hemangiomatosis with recombinant interferon $\alpha$-2a. N. Engl. J. Med. 320:1197-1200.

4.Figg, W.D., J.M. Pluda, R.M. Lush, M.W. Saville, K. Wyvill, E. Reed, and R. Yarchoan. 1997. The pharmacokinetics of TNP-470, a new angiogenesis inhibitor. Pharmacotherapy 17:91-97.

4a.Folkman, J. 1995. Angiogenesis in cancer, vascular, rheumatoid and other disease. Nat. Med. 1:27-31.

5.Yancopoulos, G.D., S. Davis, N.W. Gale, J.S. Rudge, S.J. Wiegand, and J. Holash. 2000. Vascular-specific growth factors and blood vessel formation. Nature 407:242-248.

6.Boehm, T., J. Folkman, T. Browder, and M.S. O'Reilly. 1997. Antiangiogenic therapy of experimental cancer does not induce acquired drug resistance. Nature 390:404-407.

7.Kerbel, R.S. 1997. A cancer therapy resistant to resistance. Nature 390:335336.

8.Kaban, L.B., J.B. Mulliken, R.A. Ezekowitz, D. Ebb, P.S. Smith, and J. Folkman. 1999. Antiangiogenic therapy of a recurrent giant cell tumor of the mandible with interferon $\alpha$-2a. Pediatrics 103:1145-1149.

9.O'Reilly, M.S., L. Holmgren, C. Chen, and J. Folkman. 1996. Angiostatin induces and sustains dormancy of human primary tumors in mice. Nat. Med. 2:689-692.

10.Bold, G., K.H. Altmann, J. Frei, M. Lang, P.W. Manley, P. Traxler, B. Wietfeld, J. Bruggen, et al. 2000. New anilinophthalazines as potent and orally well absorbed inhibitors of the VEGF receptor tyrosine kinases useful as antagonists of tumor-driven angiogenesis. J. Med. Chem. 43:2310-2323.

11.Relf, M., S. LeJeune, P.A. Scott, S. Fox, K. Smith, R. Leek, A. Moghaddam, R. Whitehouse, et al. 1997. Expression of the angiogenic factors vascular endothelial cell growth factor, acidic and basic fibroblast growth factor, tumor growth factor $\beta$-1, platelet-derived endothelial cell growth factor, placenta growth factor, and pleiotrophin in human primary breast cancer and its relation to angiogenesis. Cancer Res. 57:963-969.

12.Keck, P.J., S.D. Hauser, G. Krivi, K. Sanzo, T. Warren, J. Feder, and D.T. Connolly. 1989. Vascular permeability factor, an endothelial cell mitogen related to PDGF. Science 246:1309-1312.

13.Bruns, C.J., M.T. Harbison, D.W. Davis, C.A. Portera, R. Tsan, D.J. McConkey, D.B. Evans, J.L. Abbruzzese, et al. 2000. Epidermal growth factor receptor blockade with $\mathrm{C} 225$ plus gemcitabine results in regression of human pancreatic carcinoma growing orthotopically in nude mice by antiangiogenic mechanisms. Clin. Cancer Res. 6:1936-1948.

14.Inoue, K., J.W. Slaton, D.W. Davis, D.J. Hicklin, D.J. McConkey, T. Karashima, R. Radinsky, and C.P. Dinney. 2000. Treatment of human metastatic transitional cell carcinoma of the bladder in a murine model with the anti-vascular endothelial growth factor receptor monoclonal antibody DC101 and paclitaxel. Clin. Cancer Res. 6:2635-2643.

15.Ozawa, S., H. Shinohara, H.O. Kanayama, C.J. Bruns, C.D. Bucana, L.M. Ellis, D.W. Davis, and I.J. Fidler. 2001. Suppression of angiogenesis and therapy of human colon cancer liver metastasis by systemic administration of interferon- $\alpha$. Neoplasia 3:154-164.

16.Ciardiello, F. and G. Tortora. 2001. A novel approach in the treatment of cancer: targeting the epidermal growth factor receptor. Clin. Cancer Res. 7:2958-2970

17.Kerbel, R.S., J. Yu, J. Tran, S. Man, A. Viloria-Petit, G. Klement, B.L. Coomber, and J. Rak. 2001. Possible mechanisms of acquired resistance to anti-angiogenic drugs: implications for the use of combination therapy approaches. Cancer Metastasis Rev. 20:79-86.

18.Kerbel, R. and J. Folkman. 2002. Clinical translation of angiogenesis inhibitors. Nat. Rev. Cancer 2:727-739.

19.Ullrich, A., L. Coussens, J.S. Hayflick, T.J. Dull, A. Gray, A.W. Tam, J. Lee, Y. Yarden, et al. 1984. Human epidermal growth factor receptor cDNA sequence and aberrant expression of the amplified gene in A431 epidermoid carcinoma cells. Nature 309:418-425.

20.Baselga, J., D. Tripathy, J. Mendelsohn, S. Baughman, C.C. Benz, L. Dantis, N.T. Sklarin, A.D. Seidman, et al. 1999. Phase II study of weekly intravenous trastuzumab (Herceptin) in patients with HER2/neu-overexpressing metastatic breast cancer. Semin. Oncol. 26:78-83.

21.Vogel, C.L., M.A. Cobleigh, D. Tripathy, J.C. Gutheil, L.N. Harris, L. Fehrenbacher, D.J. Slamon, M. Murphy, et al. 2001. First-line Herceptin monotherapy in metastatic breast cancer. Oncology 61 Suppl 2:37-42.

22.Persons, D.L., M.M. Bui, M.C. Lowery, H.F. Mark, J.F. Yung, J.M. Birkmeier, E.Y. Wong, S.J. Yang, et al. 2000. Fluorescence in situ hybridization (FISH) for detection of HER-2/neu amplification in breast cancer: a multicenter portability study. Ann. Clin. Lab. Sci. 30:41-48.

23.de Bono, J.S. and E.K. Rowinsky. 2002. The ErbB receptor family: a ther- 


\section{Commentary}

apeutic target for cancer. Trends Mol. Med. 8:S19-S26.

24.Albanell, J., F. Rojo, S. Averbuch, A. Feyereislova, J.M. Mascaro, R. Herbst, P. LoRusso, D. Rischin, et al. 2002. Pharmacodynamic studies of the epidermal growth factor receptor inhibitor ZD1839 in skin from cancer patients: histopathologic and molecular consequences of receptor inhibition. J. Clin. Oncol. 20:110-124

25.Baselga, J., D. Rischin, M. Ranson, H. Calvert, E. Raymond, D.G. Kieback, S.B. Kaye, L. Gianni, et al. 2002. Phase I safety, pharmacokinetic, and pharmacodynamic trial of ZD1839, a selective oral epidermal growth factor receptor tyrosine kinase inhibitor, in patients with five selected solid tumor types. J. Clin. Oncol. 20:4292-4302.

26.Herbst, R.S., A.M. Maddox, M.L. Rothenberg, E.J. Small, E.H. Rubin, J. Baselga, F. Rojo, W.K. Hong, et al. 2002. Selective oral epidermal growth factor receptor tyrosine kinase inhibitor ZD1839 is generally welltolerated and has activity in non-small-cell lung cancer and other solid tumors: results of a phase I trial. J. Clin. Oncol. 20:3815-3825.

27.Ranson, M., L.A. Hammond, D. Ferry, M. Kris, A. Tullo, P.I. Murray, V. Miller, S. Averbuch, et al. 2002. ZD1839, a selective oral epidermal growth factor receptor-tyrosine kinase inhibitor, is well tolerated and active in patients with solid, malignant tumors: results of a phase I trial. J. Clin. Oncol. 20:2240-2250.

28.Albanell, J., F. Rojo, and J. Baselga. 2001. Pharmacodynamic studies with the epidermal growth factor receptor tyrosine kinase inhibitor ZD1839. Semin. Oncol. 28:56-66.

29.Bernatchez, P.N., S. Soker, and M.G. Sirois. 1999. Vascular endothelial growth factor effect on endothelial cell proliferation, migration, and plateletactivating factor synthesis is Flk-1-dependent. J. Biol. Chem. 274:3104731054.

30.Hubbard, S.R. 1999. Structural analysis of receptor tyrosine kinases. Prog. Biophys. Mol. Biol. 71:343-358.

31.Millauer, B., S. Wizigmann-Voos, H. Schnurch, R. Martinez, N.P. Moller, W. Risau, and A. Ullrich. 1993. High affinity VEGF binding and developmental expression suggest Flk-1 as a major regulator of vasculogenesis and angiogenesis. Cell 72:835-846.

32.Quinn, T.P., K.G. Peters, C. De Vries, N. Ferrara, and L.T. Williams. 1993. Fetal liver kinase 1 is a receptor for vascular endothelial growth factor and is selectively expressed in vascular endothelium. Proc. Natl. Acad. Sci. USA 90:7533-7537.

33.Millauer, B., L.K. Shawver, K.H. Plate, W. Risau, and A. Ullrich. 1994. Glioblastoma growth inhibited in vivo by a dominant-negative Flk-1 mutant. Nature 367:576-579.

34.Kuenen, B.C., L. Rosen, E.F. Smit, M.R. Parson, M. Levi, R. Ruijter, H. Huisman, M.A. Kedde, et al. 2002. Dose-finding and pharmacokinetic study of cisplatin, gemcitabine, and SU5416 in patients with solid tumors. J. Clin. Oncol. 20:1657-1667.

35.Stopeck, A., M. Sheldon, M. Vahedian, G. Cropp, R. Gosalia, and A. Hannah. 2002. Results of a phase I dose-escalating study of the antiangiogenic agent, SU5416, in patients with advanced malignancies. Clin. Cancer Res. 8:2798-2805.

36.Chambers, A.F. and L.M. Matrisian. 1997. Changing views of the role of matrix metalloproteinases in metastasis. J. Natl. Cancer Inst. 89:1260-1270.

37.Liotta, L.A. and W.G. Stetler-Stevenson. 1990. Metalloproteinases and cancer invasion. Semin. Cancer Biol. 1:99-106.

38.Murray, G.I., M.E. Duncan, P. O'Neil, W.T. Melvin, and J.E. Fothergill. 1996. Matrix metalloproteinase-1 is associated with poor prognosis in colorectal cancer. Nat. Med. 2:461-462

39.Rowinsky, E.K., R. Humphrey, L.A. Hammond, C. Aylesworth, L. Smetzer, M. Hidalgo, M. Morrow, L. Smith, et al. 2000. Phase I and pharmacologic study of the specific matrix metalloproteinase inhibitor BAY 129566 on a protracted oral daily dosing schedule in patients with solid malignancies. J. Clin. Oncol. 18:178-186.

40.Shepherd, F.A., G. Giaccone, L. Seymour, C. Debruyne, A. Bezjak, V. Hirsh, M. Smylie, S. Rubin, et al. 2002. Prospective, randomized, doubleblind, placebo-controlled trial of marimastat after response to first-line chemotherapy in patients with small-cell lung cancer: a trial of the National Cancer Institute of Canada-Clinical Trials Group and the European Organization for Research and Treatment of Cancer. J. Clin. Oncol. 20:4434-4439.

41.Levitt, N.C., F.A. Eskens, K.J. O'Byrne, D.J. Propper, L.J. Denis, S.J. Owen, L. Choi, J.A. Foekens, et al. 2001. Phase I and pharmacological study of the oral matrix metalloproteinase inhibitor, MMI270 (CGS27023A), in patients with advanced solid cancer. Clin. Cancer Res. 7:1912-1922

42.Rudek, M.A., W.D. Figg, V. Dyer, W. Dahut, M.L. Turner, S.M. Steinberg, D.J. Liewehr, D.R. Kohler, et al. 2001. Phase I clinical trial of oral COL-3, a matrix metalloproteinase inhibitor, in patients with refractory metastatic cancer. J. Clin. Oncol. 19:584-592.

43.Herbst, R.S., T.L. Madden, H.T. Tran, G.R. Blumenschein, Jr., C.A. Meyers, L.F. Seabrooke, F.R. Khuri, V.K. Puduvalli, et al. 2002. Safety and pharmacokinetic effects of TNP-470, an angiogenesis inhibitor, combined with paclitaxel in patients with solid tumors: evidence for activity in non-small-cell lung cancer. J. Clin. Oncol. 20:4440-4447.

44.O'Reilly, M.S. 2002. The combination of antiangiogenic therapy with other modalities. Cancer J. 8(Suppl 1):S89-S99.

45.Brewer, G.J., R.D. Dick, D.K. Grover, V. LeClaire, M. Tseng, M. Wicha, K. Pienta, B.G. Redman, et al. 2000. Treatment of metastatic cancer with tetrathiomolybdate, an anticopper, antiangiogenic agent: phase I study. Clin. Cancer Res. 6:1-10.

46.Simon, R., B. Freidlin, L. Rubinstein, S.G. Arbuck, J. Collins, and M.C. Christian. 1997. Accelerated titration designs for phase I clinical trials in oncology. J. Natl. Cancer Inst. 89:1138-1147.

47.Herbst, R.S., A.T. Lee, H.T. Tran, and J.L. Abbruzzese. 2001. Clinical studies of angiogenesis inhibitors: the University of Texas MD Anderson Center trial of human endostatin. Curr. Oncol. Rep. 3:131-140.

48.Herbst, R.S., N.A. Mullani, D.W. Davis, K.R. Hess, D.J. McConkey, C. Charnsangavej, M.S. O'Reilly, H.W. Kim, et al. 2002. Development of biologic markers of response and assessment of antiangiogenic activity in a clinical trial of human recombinant endostatin. J. Clin. Oncol. 20:38043814

49.Braybrooke, J.P., K.J. O'Byrne, D.J. Propper, A. Blann, M. Saunders, N. Dobbs, C. Han, J. Woodhull, et al. 2000. A phase II study of razoxane, an antiangiogenic topoisomerase II inhibitor, in renal cell cancer with assessment of potential surrogate markers of angiogenesis. Clin. Cancer Res. 6:4697-4704

50.Mancuso, P., A. Burlini, G. Pruneri, A. Goldhirsch, G. Martinelli, and F. Bertolini. 2001. Resting and activated endothelial cells are increased in the peripheral blood of cancer patients. Blood 97:3658-3661.

51.Lyden, D., K. Hattori, S. Dias, C. Costa, P. Blaikie, L. Butros, A. Chadburn, B. Heissig, et al. 2001. Impaired recruitment of bone-marrow-derived endothelial and hematopoietic precursor cells blocks tumor angiogenesis and growth. Nat. Med. 7:1194-1201.

52.Rafii, S., D. Lyden, R. Benezra, K. Hattori, and B. Heissig. 2002. Vascular and haematopoietic stem cells: novel targets for anti-angiogenesis therapy? Nat. Rev. Cancer 2:826-835.

53.Rademacher, A., M. Paulitschke, R. Meyer, and R. Hetzer. 2001. Endothelialization of PTFE vascular grafts under flow induces significant cell changes. Int. J. Artif. Organs 24:235-242

54.Lee, K.H. 2001. Proteomics: a technology-driven and technology-limited discovery science. Trends Biotechnol. 19:217-222.

55.George, D. 2001. Platelet-derived growth factor receptors: a therapeutic target in solid tumors. Semin. Oncol. 28:27-33.

56.Ostman, A. and C.H. Heldin. 2001. Involvement of platelet-derived growth factor in disease: development of specific antagonists. Adv. Cancer Res. 80:1-38.

57.Pantazis, P., P.G. Pelicci, R. Dalla-Favera, and H.N. Antoniades. 1985 Synthesis and secretion of proteins resembling platelet-derived growth factor by human glioblastoma and fibrosarcoma cells in culture. Proc. Natl. Acad. Sci. USA 82:2404-2408.

58.Uehara, H., S.J. Kim, T. Karashima, D.L. Shepherd, D. Fan, R. Tsan, J.J. Killion, C. Logothetis, et al. 2003. Effects of blocking platelet-derived growth factor-receptor signaling in a mouse model of experimental prostate cancer bone metastases. J. Natl. Cancer Inst. 95:458-470.

59.Shaheen, R.M., D.W. Davis, W. Liu, B.K. Zebrowski, M.R. Wilson, C.D. Bucana, D.J. McConkey, et al. 1999. Antiangiogenic therapy targeting the tyrosine kinase receptor for vascular endothelial growth factor receptor inhibits the growth of colon cancer liver metastasis and induces tumor and endothelial cell apoptosis. Cancer Res. 59:5412-5416.

60.Mundhenke, C., J.P. Thomas, G. Wilding, F.T. Lee, F. Kelzc, R. Chappell, R. Neider, L.A. Sebree, et al. 2001. Tissue examination to monitor antiangiogenic therapy: a phase I clinical trial with endostatin. Clin. Cancer Res. 7:3366-3374

61.Inoue, K., J.W. Slaton, P. Perrotte, D.W. Davis, C.J. Bruns, D.J. Hicklin, D.J. McConkey, P. Sweeney, et al. 2000. Paclitaxel enhances the effects of the anti-epidermal growth factor receptor monoclonal antibody ImClone $\mathrm{C} 225$ in mice with metastatic human bladder transitional cell carcinoma. Clin. Cancer Res. 6:4874-4884.

62.Davis, D.W., T.A. Buchholz, K.R. Hess, A.A. Sahin, V. Valero, and D.J. McConkey. 2003. Automated quantification of apoptosis after neoadjuvant chemotherapy for breast cancer: early assessment predicts clinical response. Clin. Cancer Res. 9:955-960

63.St. Croix, B., C. Rago, V. Velculescu, G. Traverso, K.E. Romans, E. 
Montgomery, A. Lal, G.J. Riggins, et al. 2000. Genes expressed in human tumor endothelium. Science 289:1197-1202.

64.Kobayashi, T., M. Yamaguchi, S. Kim, J. Morikawa, S. Ogawa, S. Ueno, E. Suh, E. Dougherty, et al. 2003. Microarray reveals differences in both tumors and vascular specific gene expression in de novo CD5+ and CD5diffuse large B-cell lymphomas. Cancer Res. 63:60-66.

65.Kohn, E.C., E. Reed, G.A. Sarosy, L. Minasian, K.S. Bauer, F. BostickBruton, V. Kulpa, E. Fuse, et al. 2001. A phase I trial of carboxyamido-triazole and paclitaxel for relapsed solid tumors: potential efficacy of the combination and demonstration of pharmacokinetic interaction. Clin. Cancer Res. 7:1600-1609.

66.Richardson, P.G., R.L. Schlossman, E. Weller, T. Hideshima, C. Mitsiades, F. Davies, R. LeBlanc, L.P. Catley, et al. 2002. Immunomodulatory drug CC-5013 overcomes drug resistance and is well tolerated in patients with relapsed multiple myeloma. Blood 100:3063-3067.

67.Gutheil, J.C., T.N. Campbell, P.R. Pierce, J.D. Watkins, W.D. Huse, D.J. Bodkin, and D.A. Cheresh. 2000. Targeted antiangiogenic therapy for cancer using Vitaxin: a humanized monoclonal antibody to the integrin alphavbeta3. Clin. Cancer Res. 6:3056-3061.

68.Brivio, F., P. Lissoni, F. Rovelli, A. Nespoli, F. Uggeri, L. Fumagalli, and G. Gardani. 2002. Effects of IL-2 preoperative immunotherapy on surgeryinduced changes in angiogenic regulation and its prevention of VEGF increase and IL-12 decline. Hepatogastroenterology 49:385-387.

69. Baidas, S.M., E.P. Winer, G.F. Fleming, L. Harris, J.M. Pluda, J.G. Crawford, H. Yamauchi, C. Isaacs, et al. 2000. Phase II evaluation of thalidomide in patients with metastatic breast cancer. J. Clin. Oncol. 18:2710-2717.

70.Daliani, D.D., C.N. Papandreou, P.F. Thall, X. Wang, C. Perez, R. Oliva, L. Pagliaro, and R. Amato. 2002. A pilot study of thalidomide in patients with progressive metastatic renal cell carcinoma. Cancer 95:758-765.

71.Escudier, B., N. Lassau, D. Couanet, E. Angevin, F. Mesrati, S. Leborgne, A. Garofano, C. Leboulaire, et al. 2002. Phase II trial of thalidomide in renal-cell carcinoma. Ann. Oncol. 13:1029-1035.

72.Gutheil, J. and D. Finucane. 2000. Thalidomide therapy in refractory solid tumour patients. Br. J. Haematol. 110:754

73.Figg, W.D., P. Arlen, J. Gulley, P. Fernandez, M. Noone, K. Fedenko, M. Hamilton, C. Parker, et al. 2001. A randomized phase II trial of docetaxel (taxotere) plus thalidomide in androgen-independent prostate cancer. Semin. Oncol. 28:62-66.

74.Short, S.C., D. Traish, A. Dowe, F. Hines, M. Gore, and M. Brada. 2001 Thalidomide as an anti-angiogenic agent in relapsed gliomas. J. Neurooncol. 51:41-45.

75.Heath, E.I., S. O'Reilly, R. Humphrey, P. Sundaresan, R.C. Donehower, S. Sartorius, M.J. Kennedy, D.K. Armstrong, et al. 2001. Phase I trial of the matrix metalloproteinase inhibitor BAY12-9566 in patients with advanced solid tumors. Cancer Chemother. Pharmacol. 48:269-274.

76.Bhargava, P., J.L. Marshall, W. Dahut, N. Rizvi, N. Trocky, J.I. Williams, H. Hait, S. Song, et al. 2001. A phase I and pharmacokinetic study of squalamine, a novel antiangiogenic agent, in patients with advanced cancers. Clin. Cancer Res. 7:3912-3919.

77.Galbraith, S.M., G.J. Rustin, M.A. Lodge, N.J. Taylor, J.J. Stirling, M. Jameson, P. Thompson, D. Hough, et al. 2002. Effects of 5,6-dimethylxanthenone-4-acetic acid on human tumor microcirculation assessed by dynamic contrast-enhanced magnetic resonance imaging. J. Clin. Oncol. 20:3826-3840.

78.Eder, J.P., Jr., J.G. Supko, J.W. Clark, T.A. Puchalski, R. Garcia-Carbonero, D.P. Ryan, L.N. Shulman, J. Proper, et al. 2002. Phase I clinical trial of recombinant human endostatin administered as a short intravenous infusion repeated daily. J. Clin. Oncol. 20:3772-3784.

79.Herbst, R.S., K.R. Hess, H.T. Tran, J.E. Tseng, N.A. Mullani, C. Charnsangavej, T. Madden, D.W. Davis, et al. 2002. Phase I study of recombinant human endostatin in patients with advanced solid tumors. J. Clin. Oncol. 20:3792-3803.

80.Thomas, J.P., R.Z. Arzoomanian, D. Alberti, R. Marnocha, F. Lee, A. Friedl, K. Tutsch, A. Dresen, et al. 2003. Phase I pharmacokinetic and pharmacodynamic study of recombinant human endostatin in patients with advanced solid tumors. J. Clin. Oncol. 21:223-231.

81.Turetschek, K., A. Preda, E. Floyd, D.M. Shames, V. Novikov, T.P. Roberts, J.M. Wood, Y. Fu, et al. 2002. MRI monitoring of tumor response to a novel VEGF tyrosine kinase inhibitor in an experimental breast cancer model. Acad. Radiol. 9(Suppl) 2:S519-S520.

82.Jayson, G.C., J. Zweit, A. Jackson, C. Mulatero, P. Julyan, M. Ranson, L. Broughton, J. Wagstaff, et al. 2002. Molecular imaging and biological evaluation of HuMV833 anti-VEGF antibody: implications for trial design of antiangiogenic antibodies. J. Natl. Cancer Inst. 94:1484-1493.
83.Gordon, M.S., K. Margolin, M. Talpaz, G.W. Sledge, Jr., E. Holmgren, R. Benjamin, S. Stalter, S. Shak, et al. 2001. Phase I safety and pharmacokinetic study of recombinant human anti-vascular endothelial growth factor in patients with advanced cancer. J. Clin. Oncol. 19:843-850.

84. Sandberg, J.A., V.P. Parker, K.S. Blanchard, D. Sweedler, J.A. Powell, A. Kachensky, L. Bellon, N. Usman, et al. 2000. Pharmacokinetics and tolerability of an antiangiogenic ribozyme (ANGIOZYME) in healthy volunteers. J. Clin. Pharmacol. 40:1462-1469.

85.Chen, H.X., R.E. Gore-Langton, and B.D. Cheson. 2001. Clinical trials referral resource: current clinical trials of the anti-VEGF monoclonal antibody bevacizumab. Oncology 15:1017-1026.

86.Kabbinavar, F., H.I. Hurwitz, L. Fehrenbacher, N.J. Meropol, W.F. Novotny, G. Lieberman, S. Griffing, and E. Bergsland. 2003. Phase II, randomized trial comparing bevacizumab plus fluorouracil (FU)/leucovorin (LV) with FU/LV alone in patients with metastatic colorectal cancer. J. Clin. Oncol. 21:60-65.

87.Agarwala, S.S. and J.M. Kirkwood. 2003. Temozolomide in combination with interferon $\alpha-2 b$ in patients with metastatic melanoma: a phase I doseescalation study. Cancer 97:121-127.

88.Bier, H., K.A. Reiffen, I. Haas, and P. Stasiecki. 1995. Dose-dependent access of murine anti-epidermal growth factor receptor monoclonal antibody to tumor cells in patients with advanced laryngeal and hypopharyngeal carcinoma. Eur. Arch. Otorhinolaryngol. 252:433-439.

89.Schober, R., T. Bilzer, A. Waha, G. Reifenberger, W. Wechsler, A. von Deimling, O.D. Wiestler, M. Westphal, et al. 1995. The epidermal growth factor receptor in glioblastoma: genomic amplification, protein expression, and patient survival data in a therapeutic trial. Clin. Neuropathol. 14:169174

90.Robert, F., M.P. Ezekiel, S.A. Spencer, R.F. Meredith, J.A. Bonner, M.B. Khazaeli, M.N. Saleh, D. Carey, et al. 2001. Phase I study of anti-epidermal growth factor receptor antibody cetuximab in combination with radiation therapy in patients with advanced head and neck cancer. J. Clin. Oncol. 19:3234-3243.

91.Gupta, A.K., W.G. McKenna, C.N. Weber, M.D. Feldman, J.D. Goldsmith, R. Mick, M. Machtay, D.I. Rosenthal, et al. 2002. Local recurrence in head and neck cancer: relationship to radiation resistance and signal transduction. Clin. Cancer Res. 8:885-892.

92.Hidalgo, M., L.L. Siu, J. Nemunaitis, J. Rizzo, L.A. Hammond, C. Takimoto, S.G. Eckhardt, A. Tolcher, et al. 2001. Phase I and pharmacologic study of OSI-774, an epidermal growth factor receptor tyrosine kinase inhibitor, in patients with advanced solid malignancies. J. Clin. Oncol. 19:3267-3279.

93. OSI Pharmaceuticals, Genentech and Roche announce data from clinical studies of Tarceva. 2001. Expert Review of Anticancer Therapy 1:4-5.

94.Eckhardt, S.G., J. Rizzo, K.R. Sweeney, G. Cropp, S.D. Baker, M.A. Kraynak, J.G. Kuhn, M.A. Villalona-Calero, et al. 1999. Phase I an pharmacologic study of the tyrosine kinase inhibitor SU101 in patients with advanced solid tumors. J. Clin. Oncol. 17:1095-1104.

95.Ko, Y.J., E.J. Small, F. Kabbinavar, A. Chachoua, S. Taneja, D. Reese, A. DePaoli, A. Hannah, et al. 2001. A multi-institutional phase ii study of SU101, a platelet-derived growth factor receptor inhibitor, for patients with hormone-refractory prostate cancer. Clin. Cancer Res. 7:800-805.

96.Tulpule, A., D.T. Scadden, B.M. Espina, S. Cabriales, W. Howard, K. Shea, and P.S. Gill. 2000. Results of a randomized study of IM862 nasal solution in the treatment of AIDS-related Kaposi's sarcoma. J. Clin. Oncol. 18:716-723.

97.Batist, G., F. Patenaude, P. Champagne, D. Croteau, C. Levinton, C. Hariton, B. Escudier, and E. Dupont. 2002. Neovastat (AE-941) in refractory renal cell carcinoma patients: report of a phase II trial with two dose levels. Ann. Oncol. 13:1259-1263.

98.AEterna reports on its phase II trial of neovastat. 2001. Expert Review of Anticancer Therapy 1:3-4.

99.Groen, H.J., E.G. de Vries, W. Wynendaele, W.T. van der Graaf, E. Fokkema, M.J. Lechuga, I. Poggesi, L.Y. Dirix, et al. 2001. PNU145156E, a novel angiogenesis inhibitor, in patients with solid tumors: a phase I and pharmacokinetic study. Clin. Cancer Res. 7:3928-3933.

Address correspondence to:

Dr. D.W. Davis

Department of Cancer Biology, Box 173

The University of Texas M.D. Anderson Cancer Center

1515 Holcombe Boulevard

Houston, Texas 77030, USA

e-mail:dardavis@mdanderson.org 